\title{
Analysis of Organizational Readiness towards Library 4.0: A Case Study at X Library
}

\author{
Astutik Nur Qomariyah, Eva Mursidah, Yeni Anita Gonti, \& Davi \\ Wahyuni \\ Institut Teknologi Sepuluh Nopember
}

Paper Type:

Research Paper

\begin{abstract}
:
Background of the study: The reality of the inevitability of the Industrial Revolution 4.0 era that must be faced by X University and will have an impact on the X Library towards Library 4.0 has become a serious concern at $\mathrm{X}$ University. Thus, it is important to conduct a research study on the readiness of the X Library in implementing Library 4.0.

Purpose: The purpose of this study is to identify and analyze the readiness of the $\mathrm{X}$ library to implement Library 4.0 in the face of the Industrial Revolution 4.0 by referring to the TORC (Theory of Organizational Readiness for Change), in terms of five contextual factors- the policies and procedures, past experience, organizational resources (human resources and technological resources), organizational structure, and organizational culture.
\end{abstract}

Method: The research method used this study is mixed methods, which combine quantitative and qualitative approaches.

Findings: The results showed that the level of organizational readiness in implementing Library 4.0 is the mean value of 2,60. This showed that the $X$ Library is not ready, and needs some of work to implement Library 4.0

Conclusion: Based on the five contextual factors to measure organizational readiness toward Library 4.0, it showed that almost all of them are the level of not ready, but there is one factor that shows it is quite ready- the policies and procedures. The lack of organizational readiness because leadership is an important key related to contextual factors that affect the readiness of Library X towards Library 4.0.

Keywords: industrial revolution 4.0, library 4.0, organizational readiness, the university library 


\section{Introduction}

At present, the government demands a higher education in Indonesia, including that University $\mathrm{X}$ is ready to face the Industrial Revolution 4.0, where the government has launched an industrial roadmap 4.0 on April 4, 2018 which must then be followed by all stakeholders in the Ministry, Research, Technology and Higher Education (Kemenristekdikti). The industrial roadmap 4.0 is the government's road map towards a digital economy and is expected to be able to support the economy. As is known, in the era of the Industrial Revolution 4.0, digitalization, 'artificial intelligence', 'internet of things' and 'big data' played an important role in various aspects of human life, including the world of higher education.

University $\mathrm{X}$ as one of the best universities in Indonesia, responds to the roadmap for industry 4.0 as quickly as possible so that it can adapt to the direction of change in an effort to produce graduates who are able to compete and play a role in the era of the Industrial Revolution 4.0., Namely by setting 10 (ten) main strategies, among others: Digitalpreneurship; Distance Learning; IT Infrastructure / Eservices / Smart Campus; Lifelong Learning; Global Network for Academic, Research and Innovation; IOT / Big Data / Intelligence Machine; Character Building 4.0; Teaching Industry; Alignment to Industry and Public Needs; and Adaptive Environment. These ten main strategies are in line with the planning documents of University $\mathrm{X}$, both the 5-year Strategic Plan and the XU University Development Master Plan for the next 25 years.

Library $\mathrm{X}$ is a college library under the $\mathrm{X}$ University. In accordance with the Government Regulation of the Republic of Indonesia Number 24 of 2014 concerning Implementation of Law Number 43 of 2007 concerning Libraries, article 1 number 10, that "what is meant by college libraries is a library which is an integral part of educational, research and community service activities and serves as a learning resource center to support the achievement of educational goals based in tertiary institutions. " From this mandate, it is clear that university libraries, including Library X, aim to provide information needs for the academic community (students, lecturers, researchers and staff) in order to carry out the Tri Dharma Perguruan Tinggi program which includes education and teaching, research and community service.

In order to be ready to support University $\mathrm{X}$ in facing the Industrial Revolution 4.0, Library $\mathrm{X}$ should fight hard and immediately transform into library 4.0 (Library 4.0) so that it can adapt and evolve to face digital education and the 4.0 Industrial Revolution. This is as expressed by Khoir (2018) that libraries need to adopt digital technology to provide user information needs, and if they still maintain conventional services, they will be abandoned by users, and this phenomenon can result in reduced library functions and the role of librarians being disrupted.

A series of national seminars and work meetings with the theme of the Industrial Revolution 4.0 have now been and will be carried out by Library $\mathrm{X}$ as a form of effort to prepare to support University $\mathrm{X}$ in facing the Industrial Revolution 4.0 towards Library 4.0. Some of these activities included, on October 3 2018, Library X held a national seminar entitled "Libraries as Research Partners: Challenges and Strategies in the Industrial Revolution 4.0." Furthermore, in the 2019 work meeting, the theme emphasized the character development of Library X staff in welcoming the 4.0 Industrial Revolution. In addition, the X Provement 2018 program, "Library Revitalization Study Towards X University Industrial Revolution 4.0" is one of the themes that must be studied in the management category for the committee (Directorate of Human Resources and Organization of X University) in directing the participants even though previously the theme was proposed by the participants is the integration of reading rooms at $\mathrm{X}$ University. Thus, the concept of Library 4.0 at $\mathrm{X}$ University has become a serious concern.

Seeing the reality of the inevitability of the 4.0 Industrial Revolution era that must be faced and will have an impact on Library X towards Library 4.0 to support X University in facing the Industrial Revolution 4.0, it is important to conduct a research study on the readiness of library $\mathrm{X}$ in implementing Library 4.0. This is, as stated by Bandura in Weiner (2009) that greater readiness will lead to more successful implementation of change. Furthermore, Bandura also emphasized that when the readiness 
of the organization for change is high, the members of the organization are more likely to initiate change (for example, change policies, procedures, or new activities), exert greater effort in supporting change, and show greater persistence in encountered obstacles or setbacks during implementation.

Based on the description of the above background, the formulation of the problem in this research is how the readiness of the University library X to implement a Library 4.0 in order to be ready to support the University of $\mathrm{X}$ in the face of the Industrial Revolution 4.0, $\mathrm{y}$ ang measured with by TORC ( Theory of the Organizational Readiness for Change ), namely seen from policies and procedures, past experience, organizational resources (human resources and technology resources), organizational structure, and organizational culture.

The purpose of this research is to focus more on identifying and analyzing the readiness of the University X library to implement Library 4.0, namely the supporting factors and obstacles faced by the University X library in implementing Library 4.0.

\section{Research Method}

The research method used in this research is mixed methods, which combines quantitative and qualitative approaches. As Holt, et al. (2007) explained that conducting studies on organizational readiness can use quantitative or qualitative methods.

In this research, the location used in the case study analysis unit is the organization, namely Library $\mathrm{X}$ by focusing on cases or problems regarding the readiness of the organization to implement Library 4.0 in the face of the Industrial Revolution 4.0.

To obtain informants as respondents, researchers used purposive sampling method. The purposive sampling method allows researchers to obtain informants who fit the required criteria, namely all librarians in functional positions (PNS) library managers (Non PNS) with a total of 14 respondents.

The data collection techniques in this study are primary data, literature studies, and observations conducted from June 2019 to October 2019. Primary data were obtained in two ways, namely distributing questionnaires and unstructured in-depth interviews with the guided interview approach.

Data analysis is divided into two processes: qualitative and quantitative data analysis. The qualitative data obtained from the interviews were analyzed, then presented in the form of a discussion. Meanwhile, the data obtained from the questionnaire were analyzed using quantitative descriptive analysis.

To determine the level of readiness of Library $\mathrm{X}$ in implementing Library 4.0, this study used descriptive analysis, which was seen from the category of respondents' answers. The questionnaire data obtained based on the variables were grouped using 5 Likert scales. This is as explained by Sugiyono (2013) that the Likert scale is used to measure the attitudes, opinions and perceptions of a person or group of people about social phenomena. Furthermore, Nursalam (2017) states that on a Likert scale, respondents are asked for their opinions in various levels of agreement (1-5) from statements compiled by researchers. The following is the level of readiness category which can be seen in Figure 1 .

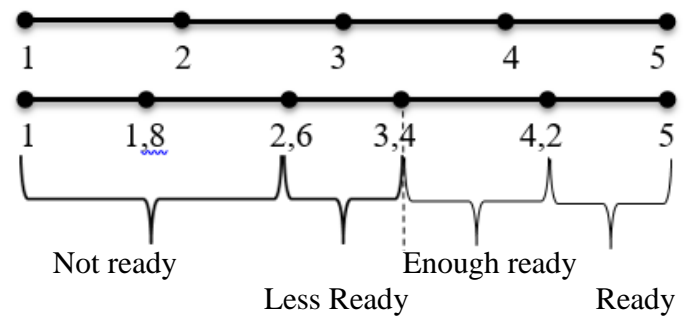

Figure 1. Level Of Readiness Category

Note: > 3.41 The minimum value of the organization is said to be quite ready 


\section{Results and Discussion}

\section{Contextual Factors of Library X's Readiness to Library 4.0}

As previously known, implementing new policies, programs or activities will generally be successful if the organization is ready, because readiness will lead to successful implementation. For this reason, a research study on the readiness of Library $\mathrm{X}$ in implementing Library 4.0 is important. As for the aspects of organizational readiness that is measured and analyzed in this study refers to the Theory of the Organizational Readiness for Change (TORC) offered by Weiner (2009), that there are factors contextual wider in affect organizational readiness through the condition, more proximal, ie 5 (five) factors as follows: 1) policies and procedures, 2) past experiences, 3) organizational resources, 4) organizational structure, and 5) organizational resources. The following are the findings related to contextual factors that affect the readiness of Library X towards Library 4.0:

\section{Policies and Procedures}

In this study, it was found that the university leadership actually encouraged Library $\mathrm{X}$ to be transformed into Library 4.0. It can be seen from Table 1 which shows that the majority of respondents as many as 11 people (78.6\%) agreed and the remaining 3 people $(21.4 \%)$ stated that they strongly agreed that (a) the leadership of my PT encouraged Library X to transform into Library 4.0. The results of this questionnaire are reinforced by the statement of one of the respondents when interviewed that:

\section{"... if the central leadership has accommodated and even freed the staff, lecturers and students to innovate ..." (Interview with Melati)}

In fact, as was previously known when on April 42018 the government demanded higher education in Indonesia to be ready to face the Industrial Revolution 4.0 as quickly as possible on April 24, 2018, University X prepared 10 main strategies as an adaptation effort to the various influences of the 4.0 Industrial Revolution (RI) in an effort produce graduates who are able to compete and play a role in the era of the Industrial Revolution 4.0 in line with the planning documents of University X, both the 5 Year Strategic Plan and the X University Development Master Plan in the next 25 years. Then, in the same, Directorate of Human Resources and Organization (SDMO) U niversitas X hold X Provement where the committee directs the librarians who followed the race to assess "Welcoming Library Revitalization Study of University X Industrial Revolution 4.0 . " Seeing this, it can be concluded that the leadership of X University moved very quickly in responding to the Industrial Revolution 4.0 and also trying to encourage Library $\mathrm{X}$ to immediately transform into a library that is in line with the era of the Industrial Revolution 4.0. One respondent said this:

"... in the future, the Chancellor wants a new field in Library X, namely the field of digital library development services. In this field, it is hoped that the library will have services according to RI 4.0... " (Interview with Prabu)

Table 1 note that respondents were 13 people (92.9\%) said they agree and the remaining $1(7.1 \%)$ said it is agreed that (b) Leadership Library X encourage the implementation of Library 4.0. Thus, most respondents stated that the leadership of Library X encouraged the implementation of Library 4.0.1 
Table 1. Policy and Procedure Factors in Library X's Readiness to Library 4.0

\begin{tabular}{|c|c|c|}
\hline \multicolumn{3}{|c|}{$\begin{array}{l}\text { a. My PT leadership encourages Library } \mathrm{X} \text { to be transformed into } \\
\text { Library } 4.0\end{array}$} \\
\hline Strongly Disagree & 0 & $0 \%$ \\
\hline Disagree & 0 & $0 \%$ \\
\hline Neutral & 0 & $0 \%$ \\
\hline Agree & 11 & $78.6 \%$ \\
\hline Strongly agree & 3 & $21.4 \%$ \\
\hline \multicolumn{3}{|c|}{ b. Library X leaders encourage the implementation of Library 4.0} \\
\hline Strongly Disagree & 0 & $0 \%$ \\
\hline Disagree & 0 & $0 \%$ \\
\hline Neutral & 0 & $0 \%$ \\
\hline Agree & 13 & $92.9 \%$ \\
\hline Strongly agree & 1 & $7.1 \%$ \\
\hline \multicolumn{3}{|c|}{ c. My library has a strategy in implementing Library 4.0} \\
\hline Strongly Disagree & 2 & $14.3 \%$ \\
\hline Disagree & 9 & $64.3 \%$ \\
\hline Neutral & 0 & $0 \%$ \\
\hline Agree & 3 & $21.4 \%$ \\
\hline Strongly agree & 0 & $0 \%$ \\
\hline
\end{tabular}

Furthermore, it was revealed the findings of the contrast in the revelation subsequent to the contrary, in general, respondents were $9(64.3 \%)$ mengat a right not to agree that ( $\mathrm{d}$ ) library I have a strategy for implementing the Library 4.0. Thus it can be said that there are constraints in policy and procedural factors in influencing the readiness of Library X towards Library 4.0 , namely the absence of a strategy for Library $\mathrm{X}$ in implementing Library 4.0.

\section{Past Experiences}

Past experience with change can have a positive or negative impact on the change in the valence of organizational members. For example, do they think the changes will actually deliver the touted benefits and change the assessment of efficacy. For example, do they think the organization can effectively carry out and coordinate change-related activities. So, positive past experiences with change can foster organizational readiness (Weiner: 2019).

\begin{tabular}{|c|c|c|}
\hline \multicolumn{3}{|c|}{$\begin{array}{l}\text { a. There is communication between the Head of Library } X \text { and the } \\
\text { librarian before implementing a program }\end{array}$} \\
\hline Strongly Disagree & 2 & $14.3 \%$ \\
\hline Disagree & 1 & $7.1 \%$ \\
\hline Neutral & 0 & $0 \%$ \\
\hline Agree & 10 & $71.4 \%$ \\
\hline Strongly agree & 1 & $7.1 \%$ \\
\hline \multicolumn{3}{|c|}{$\begin{array}{l}\text { b. There is always planning (planning) in the implementation of a } \\
\text { program }\end{array}$} \\
\hline Strongly Disagree & 3 & $21.4 \%$ \\
\hline Disagree & 8 & $57.1 \%$ \\
\hline Neutral & 0 & $0 \%$ \\
\hline Agree & 3 & $21.4 \%$ \\
\hline Strongly agree & 0 & $0 \%$ \\
\hline
\end{tabular}

Source: questionnaire data

In this study, past experience aims to determine the implementation process, namely, whether any programs are communicated and planned for the future. From the results of the questionnaire shown in Table 2, there are contrasting findings on past experience factors, where the majority of respondents as many as 10 people (71.4\%) said they agreed that (a) there was communication between the Head of Library $\mathrm{X}$ and the librarian before implementing a program. However, furthermore, most of them stated that as many as 8 people (57.1\%) disagreed that (b) there was always planning in a program. It can be 
said that there is a communication that exists between the Leaders Library $\mathrm{X}$ and librarians about a program but there is no planning in Implementation. Thus, it can be concluded that there were obstacles in the past, experience factors in influencing the readiness of Library X towards Library 4.0, namely the absence of planning in a program. In fact, as revealed David (2009) that planning is one of the most important management functions for a variety of other management functions new role when planning is implemented and should be guided by the planning that has been set.

\section{Organizational Resources}

The aspects of organizational resources that affect the readiness of the organization towards Library 4.0 which are measured in this research include human resources and technological resources. As is well known, human resources are an important factor in an organization. For this reason, a qualified librarian at Library $\mathrm{X}$ is a must and the main requirement that needs to be considered and improved is by continuously updating the knowledge, skills, and work attitudes of the librarians so that they are ready to go to Library 4.0. This is in line with what Rohmadi (2018) expressed in a Focus Group Discussion (FGD) with the theme "Development of Library Management in the Era of 4.0", that the initial key to dealing with technology in the 4.0 era is starting from the manager or librarian.

Noh (2015) said that library management 4.0 has at least some competencies that library managers need to have, including understanding and being able to use semantic web technology, metadata, searching ontology, mobile applications, artificial intelligence, context-awareness, cloud computing, big data, augmented reality; And able to legally conceptualize digital library maker space services.

Just like with Noh, associated competencies that need to be owned by the manager of Library 4.0, more Wasitarini and chaerul umam (2018) mapped the competence of librarians towards Library 4.0, where the competencies required include: Internet of Thing, technology digital, big data analytics, robots, cyber security, cloud computing and AR (Augmented Reality).

Below is Table 3.1 which shows the competence of human resources in the readiness of Library $\mathrm{X}$ towards Library 4.0. From the table, it is known that in general the respondents admit that they do not have the competence to manage the Library 4.0. This can be seen from the number of respondents as many as 13 people $(92.9 \%)$ said they did not agree and the remaining 1 person $(7.1 \%)$ said they strongly disagreed that they had competence in Internet of Thing technology, digital technology, big data analytics, robots, cyber security, cloud computing and AR (Augmented Reality). The same result was also shown by 13 respondents $(92.9 \%)$ who disagreed and the remaining 1 person $(7.1 \%)$ said they strongly disagreed that they had the ability to legally conceptualize digital library maker space services.

Table 3. Human Resources in the Readiness of Library X towards Library 4.0

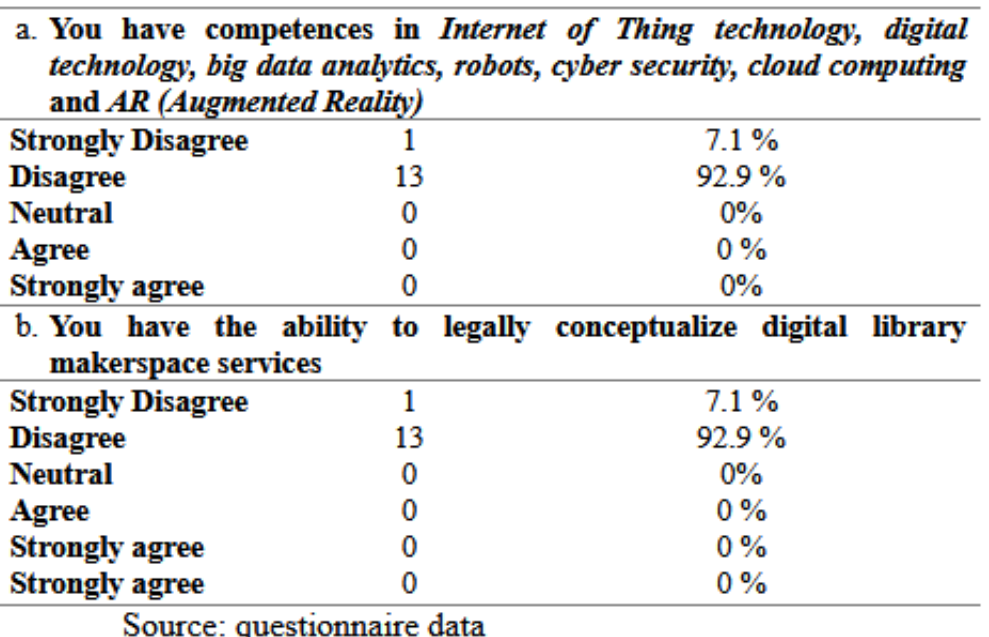

Source: questionnaire data 
Furthermore, to implement Library 4.0, a good information technology infrastructure is needed. Based on Table 3.2, it is known that the majority of respondents as many as 12 people $(85.7 \%)$ stated that they did not agree that (a) the library has an information technology infrastructure that supports the implementation of Library 4.0 while the remaining 2 people $(14.3 \%)$ agreed. This means that librarians see that their library lacks information technology infrastructure to support the implementation of Library 4.0.

Besides, the inadequate condition of the technological infrastructure is also found that the library lacks skills in information technology. Seen from Table 3.2 shows as many as 10 people (71.4\%) said that did not agree and as many as four people (28.6\%) said it was not agreed that (b) Library I have the skills (skills) in information technology that supports the implementation of Library 4.0. This fact is reinforced by the results of previous findings on the aspect of human resources which note that all respondents lack the competence in managing Library 4.0. This means that there are similar problems between aspects of information technology infrastructure and librarian competence in implementing Library 4.0, namely librarians see a librarian competency problem, while at the same time they also think about the lack of information technology infrastructure. As stated by Dewa, one respondent said:

\section{"... here there are only 2 staff in IT services so development is difficult, especially since the IT knowledge is also limited" (Interview with Dewa)}

Table 4. Technology Resources in the Readiness of Library X towards Library 4.0

\begin{tabular}{|c|c|c|}
\hline \multicolumn{3}{|c|}{$\begin{array}{l}\text { a. My library has information technology infrastructure that supports } \\
\text { the implementation of Library } 4.0\end{array}$} \\
\hline Strongly Disagree & 0 & $0 \%$ \\
\hline Disagree & 12 & $85.7 \%$ \\
\hline Neutral & 0 & $0 \%$ \\
\hline Agree & 2 & $14.3 \%$ \\
\hline Strongly agree & 0 & $0 \%$ \\
\hline \multicolumn{3}{|c|}{$\begin{array}{l}\text { b. My library has skills in information technology that support the } \\
\text { implementation of Library } 4.0\end{array}$} \\
\hline Strongly Disagree & 4 & $28.6 \%$ \\
\hline Disagree & 10 & $71.4 \%$ \\
\hline Neutral & 0 & $0 \%$ \\
\hline Agree & 0 & $0 \%$ \\
\hline Strongly agree & 0 & $0 \%$ \\
\hline
\end{tabular}

\section{Organizational Structure}

According to Stueart and Moran (2007), organizational structure is the source of how responsibility is distributed, how individual positions are coordinated, and how this information is formally disseminated. When the organizational structure changes, the process is referred to as restructuring or reorganization. Traditionally, many managers have been reluctant to change organizational structures once established. This may be due to fear of change or failure to recognize that new activities require a new or modified organizational structure.

In line with Noh (2015) regarding the competencies that library managers need to have, further Wasitarini and Chaerul Umam (2018) map librarian competencies against Library 4.0, where the competencies that must be possessed include: Internet of Thing, digital, big data, robots, cyber security, cloud computing and AR (Augmented Reality). This means that libraries can implement Library 4.0 if in their organizational structure, there is a digital technology field or division that has staff with these competencies to develop digital library services in accordance with Library 4.0.

Based on the results of the study, 14 respondents (100\%) said that they do not have a dedicated digital technology division to support the implementation of Library 4.0, such as: Internet of Thing, digital, big data, robots, cyber security, cloud computing and AR (Augmented Reality). The X Library 
currently has a division or field of information technology, but is only focused on maintenance, hardware, software, and digital libraries.

Table 5. Organizational Structure in the Readiness of Library X towards Library 4.0

\begin{tabular}{lcc}
\hline $\begin{array}{l}\text { The library has a digital technology division / field to support the } \\
\text { implementation of Library }\end{array}$. \\
\hline Strongly Disagree & 0 & $0 \%$ \\
Disagree & 14 & $100 \%$ \\
Neutral & 0 & $0 \%$ \\
Agree & 0 & $0 \%$ \\
Strongly agree & 0 & $0 \%$ \\
\hline
\end{tabular}

Source: questionnaire data

\section{Organizational Culture}

Every organization, whatever its form must have a culture. Organizational culture is a factor that determines the key characteristics of an organization's value. As stated by Robbins (2003), organizational culture is a system of shared meaning held by its members that differentiates an organization from other organizations. This shared meaning system is a set of key characteristics of organizational values. Edgar H. Schein (2004) explains that organizational culture comes from three sources, namely: (1) the beliefs, assumptions and values of the founders of the organization; (2) the learning experiences of group members as the organization develops and (3) new beliefs, values and assumptions brought by new members and leaders (Schein: 2004).

A lot of success can be achieved by an organization because it is supported by a distinctive culture and is strongly embedded in its operational activities. On the other hand, quite a lot of organizational failures in maintaining the continuity of the organization are caused by not paying attention to the culture that must be developed (Ndraha: 2003).

According Uwa (2014), organizational culture will affect the continuity of the implementation Changes organization. An organizational culture that tends to be resistant to change will make it difficult for companies to continue to carry out changes consistently because human resources (HR) who are the driving machines tend to be resistant to change. In fact, organizational change is a vital thing that organizations must continue to do.

Based on the results of the questionnaire are shown in Table 5 known to the majority of respondents expressed disagreement as many as eight people $(57.1 \%)$ that a trust between individuals in the Library $\mathrm{X}$ to implement a Library 4.0. Furthermore, it was revealed the same findings in the statement following that shows that in general, respondents as many as eight people $(57.1 \%)$ mengat a right not to agree that their cultures to work together and communicate with each other to solve the problems and challenges to implement a Library 4.0 thus it can be It is said that there are constraints in organizational culture factors in influencing the readiness of Library X towards Library 4.0, namely the absence of mutual trust, collaboration and communication in Library X in implementing Library 4.0.

Table 6. Organizational Culture Factors in the Readiness of Library X towards Library 4.0

\begin{tabular}{lcc}
\hline $\begin{array}{l}\text { a. There is mutual trust } \\
\text { subordinates or vice versa) }\end{array}$ & $\begin{array}{c}\text { between } \\
\text { where I work to implement Library 4.0 }\end{array}$ \\
\hline Strongly Disagree & 2 & $14.3 \%$ \\
Disagree & 8 & $57.1 \%$ \\
Neutral & 0 & $0 \%$ \\
Agree & 3 & $21.4 \%$ \\
Strongly agree & 1 & $7.1 \%$ \\
\hline b. There is a culture to work together and communicate with each \\
other to solve problems and challenges to implementing Library 4.0 \\
\hline Strongly Disagree & 2 & $14.3 \%$ \\
Disagree & 8 & $57.1 \%$ \\
Neutral & 0 & $0 \%$ \\
Agree & 3 & $21.4 \%$ \\
Strongly agree & 1 & $7.1 \%$ \\
\hline Source: questionnaire data &
\end{tabular}

To cite this document:

Qomariyah, A. N., et.al. (2020). Analysis of Organizational Readiness towards Library 4.0: A Case Study at X Library. Record and Library Journal, 6(2), 110-119.

Open access under Creative Commons Attribution-Non Commercial-Share A like 4.0 International Licence 


\section{Analysis of the Readiness Level of Library X Towards Library 4.0}

The process of calculating the readiness analysis of Library $\mathrm{X}$ in implementing Library 4.0 uses descriptive statistical methods, which is to find the average value of all questionnaire answers for each group of research variables. Based on the results of the analysis of the readiness level of Library $\mathrm{X}$ in implementing Library 4.0 as a whole, it can be concluded that Library X has a value of 2.60 which is seen in Table 7. This means that Library $\mathrm{X}$ is not ready and needs some preparation to be able to implement Library 4.0.

\begin{tabular}{lcccc}
\multicolumn{6}{l}{ Table 7. Calculation of Library } & \multicolumn{4}{l}{ Total Readiness X } \\
\hline Answer & $\mathbf{X}$ & $\mathbf{F}$ & FX & $\%$ \\
\hline $\begin{array}{l}\text { Strongly } \\
\text { Disagree }\end{array}$ & 1 & 17 & 17 & $2 \%$ \\
(STS) & & & & \\
Disagree (TS) & 2 & 96 & 192 & $19 \%$ \\
Neutral (N) & 3 & 0 & 0 & $0 \%$ \\
Agree (S) & 4 & 48 & 192 & $65 \%$ \\
Strongly & 5 & 7 & 35 & $14 \%$ \\
Agree (SS) & & 168 & 436 & $100 \%$ \\
TOTAL & & 2.60 & & \\
AVERAGE & & 32,7381 & & \\
Percentage & & $33 \%$ & & \\
F (SS) + F (S) / F (TTL) & & & \\
\hline
\end{tabular}

Source: questionnaire data

As previously explained, the measurement of organizational readiness in this study refers to Theory of Organizational Readiness for Change (TORC), namely 5 (five) factors as follows: 1) policies and procedures, 2) past experience, 3) organizational resources, 4) organizational structure, and 5) organizational culture. These factors are the variables in this study. The calculation of the average value for each variable of this study shows the level of readiness for each of these variables.

If we look at the contextual factors that affect the readiness of Library X towards Library 4.0, it is found that the level of readiness for policy and procedure factors is 3.52, the level of readiness for past experience factors is 2.86 , the level of readiness for organizational resource factors is 2,93 , the level of readiness for organizational structure is 2.00 and the level of readiness for organizational culture factors is 2.50. From the value of each of these factors, it can be seen that almost all of the factors studied are at the level not ready, with the exception of the policy and procedure factors which indicate quite ready with a value of 3.52. Behind the unpreparedness of every factor, based on the results of interviews with several respondents, it was found that leadership is an important key related to contextual factors that affect the readiness of Library X to Library 4.0.

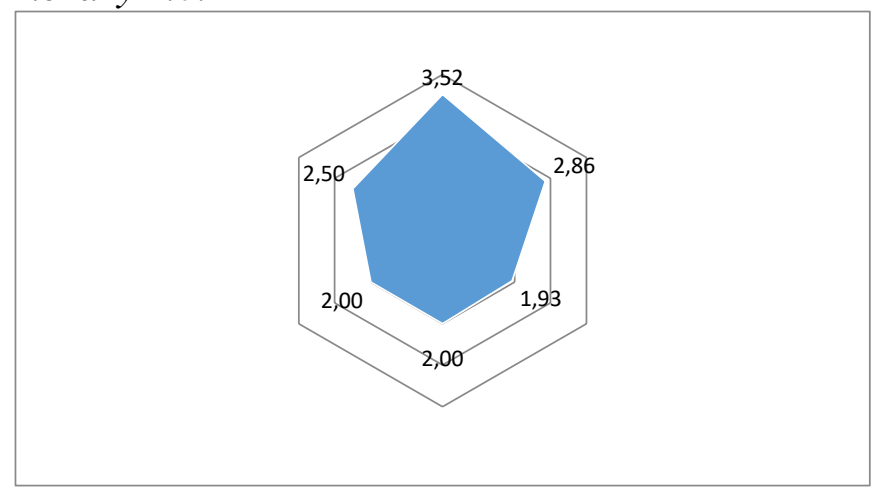

Figure 2. Radar chart measuring the readiness of Library X to Library 4.0

To cite this document:

Qomariyah, A. N., et.al. (2020). Analysis of Organizational Readiness towards Library 4.0: A Case Study at X Library. Record and Library Journal, 6(2), 110-119.

Open access under Creative Commons Attribution-Non Commercial-Share A like 4.0 International Licence 


\section{Conclusion}

The results of measuring the readiness of Library X towards Library 4.0 show that overall, most of the factors studied are at the unprepared level, namely past experience, organizational resources, organizational structure, and organizational culture. With the exception of the policy and procedure factors that show quite ready. Policy factors and procedures that support the readiness of Library X towards Library 4.0 are that the leadership of PT encourages Library X to be transformed into Library 4.0 and the leadership of Library X encourages the implementation of Library 4.0.

As for the absence of organizational readiness from each factor because leadership in Library $\mathrm{X}$ is an important key related to contextual factors that affect the readiness of Library X towards Library 4.0. Leaders should have the skills and skills to be able to recognize change, be able to formulate strategies for the changes faced, and be able to embrace all staff so that all staff in the organization can unite, trust and work together to bring change for the better.

\section{References}

David, F. R. (2009). Strategic management: Concepts and cases. Denmark: Pearson.

Holt, D. T., Armenakis, A. A., Feild, H. S., \& Harris, S. G. (2007). Readiness for Organizational Change: The Systematic Development of a Scale. The Journal of Applied Behavioral Science, 43(2), 232255. https://doi.org/10.1177/0021886306295295

Indonesia. (2014). Peraturan pemerintah nomor 24 tahun 2014 tentang pelaksanaan undang-undang nomor 43 tahun 2007 tentang perpustakaan. Jakarta: Perpustakaan Nasional.

Khoir, S. (2018). The need to change: Perilaku dan manajemen informasi dalam era normal baru. Makalah disampaikan pada Dies Natalis Ke-67 Perpustakaan Universitas Gadjah Mada tanggal 1 Maret 2018, Universitas Gadjah Mada.

Ndraha, T. (2003). Budaya Organisasi. Jakarta: Rineka Cipta.

Noh, Y. (2015). Imagining library 4.0: Creating a model for future libraries. The Journal of Academic Librarianship. http://dx.doi.org/10.1016/j.acalib.2015.08.020.

Nursalam. (2017). Metodologi penelitian ilmu keperawatan: pendekatan praktis. Jakarta: Salemba Medika.

(30 Oktober 2018). Revolusi industri 4.0, Perpustakaan UNS harus berani bertransformasi. Diambil dari https://uns.ac.id/id/uns-update/revolusi-industri-4-0-perpustakaan-uns-harus-beranibertransformasi.html

Sugiyono. (2013). Metode penelitian pendekatan kuantitatif, kualitatif, dan R\&D. Bandung: Alfabeta.

Stueart, R. D. \& Barbara B. Moran. (2007). Library and information center management. (7th ed). London: Libraries Unlimited.

Uwa, I. N. (2014). Manajemen perubahan: Teori dan aplikasi pada organisasi publik dan bisnis. Bogor: Ghalia.

Weiner, B. (2009). A theory of organizational readiness for change. Implementation Science, 4(67), 1-9. doi: 10.1186/1748-5908-4-67

Wasitarini, D. E., \& Umam, C. (2018). Peran pustakawan dalam era library 4.0. MADIKA: Media Informasi dan Komunikasi Diklat Kepustakawanan, 4(2), 7-15. Retrieved from https://ejournal.perpusnas.go.id/md/article/view/500

Schein, E. H. (2004). Organizational culture and leadership. (3rd edition). California: John Wiley \& Sons.

Robbins, S. P. (2003). Perilaku organisasi. (Jilid 2). Jakarta: Gramedia. 